A. gambiae strains. It has been suggested ${ }^{4}$ that the inhibition of multiple insemination by the female mosquito could operate as an effective isolating mechanism, barring hybridization between closely related sympatric species, races or strains. On the other hand, having once mated with a 'foreign' male, the potentiality of the particular female to contribute to the next generation of her own kind will be inhibited.

I thank Mr. G. Davidson for advice.

The Ross Institute,

London School of Hygiene and Tropical Medicine,

$$
\text { L. K, H. GomA * }
$$

Keppel Street (Gower Street),

$$
\text { London, W.C.1. }
$$

* Present address: East African Virus Research Institute, P.O. Box 49, Entebbe, Uganda.

${ }^{2}$ Bacot, A. W., Rep. Yellow Fever Comm., Lond., 3 (1916).

2 Roth, L. M., Amer. Midlife Nat., 40, 265 (1948).

- Kitzmiller, J. B., and Laven, H., Amer. J. Hyg., 67, 207 (1958).

‘ Goma, L. K. H., Ph.D. thesis, London Univ. (1962).

- Gillett, J. D., Bull. Ent. Res., 46, 241, 255 (1955).

- Rozeboom, L. E., Ann. Ent. Soc. Amer., 29, 480 (1936).

\section{Function of the Arex Porosæ of Ixodid Ticks}

THE function of the areæ porosæ of the dorsal side of the basis capituli of the female ixodid tick was unknown for $a$ long time. The tradition of considering it as an organ of unknown function has apparently been so well accepted by acarologists that, for at least the past 50 years, no attempt seems to have been made to elucidate the function. The interest of most acarologists in the porose area seems to be restricted to using its size and shape as an auxiliary character for specific diagnosis.

It can now be shown that the areæ porosæ are the outlets of the glands recently discovered and deseribed ${ }^{2}$.

Feldman-Muhsam and Havivi reported on two previously undescribed groups of accessory glands in the vicinity of Gené's organ, in gorged females of Hyalomma excavatum, Rhipicepalus sanguineus s.l. and Boophilus annulatus. The glands become evident soon after the onset of feeding, and attain full development by the time oviposition begins. It was also noted that these glands were not found in Ornithodoros tholozani.

It should be added that the glands were also found in Ixodes ricinus and Dermacentor albipictus. These additional observations suggest that these glands are present in all Ixodidae, and are absent in Argasidae.

Further examination of the morphology and development of these glands showed that the very thin and elongated ducts of these glands terminate in the arex porosæ. Each gland is apparently connected to a separate pore of the area porosa; the number of glands corresponds to the number of pores. The relationship between the areæ porosæ and these glands explains why there are no areæ porosæ in Argasidae.

Experimental interception of the flow of the glandular secretion by obstruction of the orifices of the areæ porosæ interfered with the normal functioning of Genés organ and consequently with oviposition.

During oviposition Gené's organ comes in close contact with the basis capituli; it is protruded and retracted for the laying of each egg. Thus, during oviposition Gene's organ is protruded and retracted on the average about 2,000 times in Boophilus annulatus, about 3,000 times in $R$. sanguineus s.l., about 5,000 times in $D$. andersoni, and $8,000-15,000$ times in some species of Hyalomma. It is quito obvious that such a mochanism needs a lubricating system to function smoothly.

The obliteration of the areæ porosæ showed clearly that Gene's organ is incapable of functioning without the secretion of the recently described glands.

When the orifices of the areæ porosæ are destroyed, Gené's organ stops its movements and often remains wholly or partly stuck to the basis capituli. It is therefore assumed that the main function of the glands is most probably the lubrication of the evagination-invagination mechanism of Genés organ.

This investigation was supported by research grant No. 4531 from the National Institutes of Health, U.S. Public Health Service.

\section{B. Feldman-Muhsam}

Department of Parasitology,

Hebrew University, Jerusalem.

1 Feldman-Muhsam, B., and Havivi, Y., ${ }^{\pi}$ Nature, 187, 964 (1900).

\section{MICROBIOLOGY}

\section{'Endogenous Factor' in Sporogenesis in Bacteria}

Extensive investigations on the morphological changes during sporogenesis have afforded valuable information about this phenomenon ${ }^{1}$. The initiation of sporulation can be better understood if the metabolic events during the transition from a vegetative cell to its sporulating phase are known. Several attempts have been made to investigate the physiology of growth distinct from sporulation. Foster et al. ${ }^{2}$ found that when vegetative cells of $B$. mycoids were removed from the complex growth media before the point of maximal growth and transferred to distilled water, they formed spores. This was termed 'endotrophic sporulation'. But experiments with $B$. cereus strain $T$ (phage-resistant organisms) showed that 'endotrophic sporulation' can be observed only when granulated cells were suspended in a medium containing sufficient calcium ions ${ }^{8}$. (The shortening and granulation of cells are usually noticed only long after the cessation of growth.) Non-granulated vegetative cells lysed on transfer into a non-growth supporting modium. In this communication, we report observations which lend evidence to the presence of an 'endogenous factor' involved in the initiation of the morphogenesis in the vegetative cell leading to the formation of a granulated cell (Fig. 1) possessing the ability to sporulate in a medium which does not support growth.

$B$. cereus strain $T$ (phage-sensitive) was used throughout these investigations. The cells were grown by the active culture technique from a heat-shocked spore inoculum in G medium (see legend for Table 1) and collected when they appeared granular under the phase contrast microscope (Fig. 1b). They were washed with $0.01 \mathrm{M}$ tris $p \mathrm{H}$ 7.4 suspended in $0.01 \mathrm{M}$ potassium phosphate $p \mathbf{H} 6.8$ (1/50 vol. of original medium) and sonicated in the Raytheon sonicator for 10-12 min. The broken cells and cell debris were removed by centrifugation at $15,000 \mathrm{~g}$ for $15 \mathrm{~min}$. Most of the protein in the clear supernatant was removed by acidifying with $1 \mathrm{~N}$ hydrochloric acid and centrifuging off the precipitate. The 'active principle' was

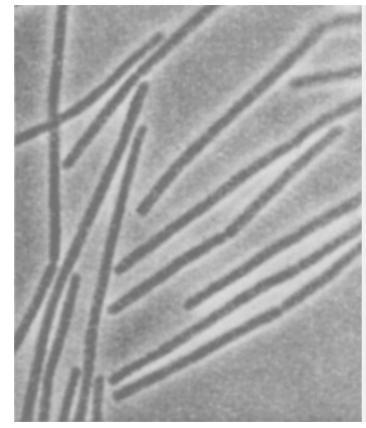

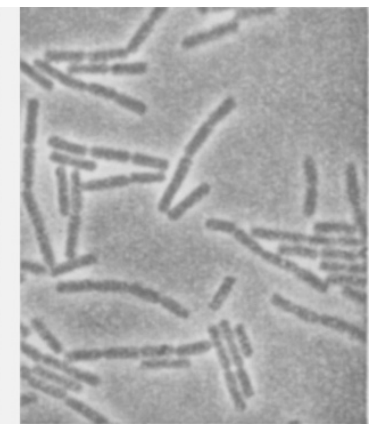

$b$ Fig. 1. Phase contrast micrograph of $(a)$ vegetative cells; $(b)$ granular 